\title{
NILAI PENDIDIKAN DALAM BUKU CERITA KARYA AVAN FATTHURRAHMAN PADA PROSES KEGIATAN BELAJAR MENGAJAR (KBM)
}

\author{
Nur Afif*, Muhammad Fianudin**, Asrori Mukhtarom*** \\ *nur.afif86@gmail.com,**fianudin11@yahoo.com, \\ ***asrorimukhtarom84@gmail.com \\ *Institut PTIQ Jakarta, \\ ***Universitas Muhammadiyyah Tangerang,
}

\begin{abstract}
Education is important for human life, moral degradation in the current generation has become a serious thing to be tackled by the world of education, especially Islamic education. One form of overcoming it is by instilling Islamic values in students. The Storybook by Avan Fathurrahman is a book in the form of a collection of stories that contain Islamic educational values, can provide good motivation for students. This study aims to find out: What values of Islamic education material are contained in Avan Fathurrahman's Storybook, and how relevant are the Islamic educational values contained in Avan Fathurrahman's Storybook with the world of education. The author uses the type of research Library Research (Library Research), namely research that collects data and information with the help of various materials contained in the literature. In addition to these methods, the author uses the story method. The values of Islamic education contained in the book collection of great Muslim children's stories by Avan Fathurrahman are: The value of aqidah/faith education, namely (faith in Allah), the value of sharia education/worship, namely (prayer, praying, giving alms, studying), the value of education morals, namely (husnudzhan, help, filial piety to parents, trustworthiness, gratitude, amar ma'ruf, apologizing/forgiving, and honest). The relevance of the values of Islamic education to the practice of Islamic education today is the importance of applying the values of Islamic education in the family environment, school environment, and community environment.
\end{abstract}

Keywords: Story, Value, Islamic Education

\section{Pendahuluan}

Kehadiran buku cerita di tengahtengah perkembangan teknologi merupakan tantangan besar, dimana buku cerita harus dapat memberi jalan inspirasi buat kehidupan yang nyata. Harus memberi jalan lurus bagi manusia dalam globalisasi zaman. Nilai-nilai moral dalam cerita membantu mereka untuk mengatasi permasalahan keseharian secara realistis ini menunjukan bahwa dengan cerita, pembaca bisa mendapatkan kebaikan dan cerminan diri mereka sendiri dalam menghadapi permasalahan yang terjadi dalam kehidupan sehari-hari. Dan yang menjadi masalah juga sebagian kecil buku cerita yang mengandung nilai-nilai moral dan teladan.

Pasalnya, para penulis atau sastrawan hanya mengambil keuntungan sejumlah uang dari hasil penjualan buku yang banyak apalagi buku cerita tersebut sampai ke tingkat best seller. Penulis atau sastrawan tersebut lupa tentang hal yang terpenting yaitu mereka juga sebagai pejuang moral dengan karya mereka yang sarat akan nilai-nilai yang baik sehingga memberikan pencerahan bagi pembacanya dari berbagai masalah yang mereka hadapi dalam kehidupan.

Istilah "belajar sambil bermain" bisa didapat dengan membaca buku cerita karena selain mendapat hiburan, pembaca juga mendapat pengetahuan, contoh teladan, dan pendidikan. Karena pendidikan 
tidak hanya didapat di lembaga formal (sekolah) saja melainkan segala yang kita lihat, kita dengar, kita rasa adalah pendidikan. Zuhairini juga menyatakan bahwa pendidikan adalah suatu aktivitas untuk mengembangkan seluruh aspek kepribadian manusia yang berjalan seumur hidup. Dengan demikian, demi meningkatkan kualitas pendidikan tidak cukup dengan melakukan aktivitas di dalam kelas saja melainkan menambah wawasan pengetahuan dan pendidikan di luar kelas pun bisa dilakukan salah satunya dengan membaca buku cerita.

Tidak hanya guru, peran orang tua pun dibutuhkan untuk menanamkan nilainilai pendidikan islam di lingkungan terkecil yaitu keluarga, dimulai dari penanaman karakter sejak dini yang mengalami ketidakseimbangan karena orangtua dari anak lebih memilih kesibukan dibandingkan membimbing anak-anak dalam pembentukan karakter. salah satunya dengan cara kegiatan bercerita di rumah. Bercerita menyangkut kehidupan anak, cerita tentang kisah para nabi dan rasul, atau orang-orang yang shaleh yang bermanfaat untuk pendidikan dan pembentukan pribadi anak.

Dengan bercerita juga adalah cara yang paling praktis untuk menanamkan nilai-nilai yang positif, karena nilai-nilai yang terkandung dalam kisah tersebut dapat diserap dengan cepat oleh otak anak hingga melekat sampai mereka dewasa. Kegiatan bercerita juga mampu mendekatkan hati dan jiwa anak-anak dengan guru atau orangtua. Dengan demikian, kegiatan bercerita akan menciptakan suasana yang hangat dan harmonis antara anak dan orang tua sehingga akan lebih mudah untuk menanamkan nilai-nilai pendidikan terutama nilai-nilai pendidikan islam didalamnya.

Dalam pendidikan Islam terdapat bermacam-macam nilai Islam yang mendukung terhadap pelaksanaan pendidikan bahkan salah satu yang terpenting digunakan untuk pengembangan jiwa anak sehingga dapat memberikan hasil yang baik bagi pendidikan Islam sehingga bisa bermanfaat bagi masyarakat maupun dunia pendidikan itu sendiri. Pendidikan Agama Islam juga bisa dikatakan sebagai proses pengubahan sikap dan tingkah laku seseorang atau kelompok orang dalam usaha mendewasakan manusia melalui upaya pengajaran pelatihan, proses perbuatan, cara mendidik yang didalamnya berlandaskan Al-Qur'an dan Sunnah Rasulullah sebagai sumber utamanya. Jadi nilai-nilai pendidikan Islam bisa dikatakan bahwa suatu proses pengembangan kepribadian peserta didik dengan mengasah dan menanamkan nilai-nilai kehidupan sehingga membentuk kepribadian yang berakhlakul karimah berlandaskan $\mathrm{Al}$ Qur'an dan Sunnah Rasulullah meliputi aspek nilai akidah, nilai syari'ah/Ibadah, dan nilai akhlak.

Dalam karya sastra seperti buku cerita juga ditemukan nilai pendidikan Islam sebagai pokok pemikiranya buku cerita ini tidak hanya fiktif belaka, tetapi juga diperkuat dengan dalil-dalil dari AlQur'an maupun hadits sehingga cerita yang dipaparkan tidak hanya sebatas menghibur semata tetapi juga sebagai nilai pendidikan.

Menurut Toha sebagaimana dikutip oleh Nadya bahwa buku cerita adalah buku yang menyuguhkan cerita dengan menggunakan gambar.

Cerita anak merupakan salah satu karya sastra anak. Sastra anak sendiri adalah karya sastra yang ditulis sebagai bacaan untuk anak, yang mana isinya sesuai tingkat perkembangan intelektual serta emosi anak. Cerita anak bisa digunakan sebagai hiburan maupun untuk memberikan anak pendidikan moral.

Dari penjelasan diatas dapat kita simpulkan bahwa buku cerita anak adalah buku yang dibuat khusus untuk anak-anak yang memuat berbagai macam gambar/visualisasi yang mana bisa membuat anak tertarik untuk membacanya, sehingga dari cerita-cerita yang sederhana dan termuat dalam buku cerita tersebut, anak-anak dapat mengambil pelajaran/ hikmah sehingga menjadi salah satu alternatif untuk mendapatkan nilai-nilai kebaikan.

Dalam hal ini, penulis berasumsi bahwa buku kumpulan cerita anak muslim 
karya Avan Fathurrahman adalah buku cerita anak yang tidak hanya memiliki visualisasi yang bagus, tetapi juga penuh dengan nilai-nilai islami.

Saat ini, Indonesia dihadapkan dengan degradasi moral yang terus menggerus generasi bangsa. Pemerintah maupun suatu lembaga pendidikan berupaya semaksimal mungkin untuk mencetak peserta didiknya agar menjadi generasi penerus bangsa yang tidak hanya memiliki pengetahuan, tetapi juga memiliki sikap yang baik. Salah satu upaya tersebut adalah menanamkan nilainilai positif sedini mungkin, sebagaimana jika suatu bangunan memiliki pondasi yang kuat, maka akan kuat pula bangunan tersebut. Jika sedini mungkin ditanamkan hal-hal positif, maka akan baik pula kehidupannya kelak.

Selain itu, peran guru juga dibutuhkan untuk menumbuhkan semangat belajar peserta didik dengan memilih strategi belajar dan model pembelajaran yang bisa membantu guru untuk menyampaikan pesan kepada siswa, agar pesan yang disampaikan kepada siswa menjadi jelas dan lebih dipahami oleh siswa, selain itu media pembelajaran juga dapat membangkitkan motivasi dan minat baru dalam diri siswa untuk belajar. Salah satu media pembelajaran tersebut adalah buku cerita.

Salah satu buku cerita yang memuat nilai-nilai positif maksud dalam hal ini adalah nilai-nilai Islami, salahsatunya adalah buku kumpulan cerita anak muslim karya avan fathurrahman. Selain cerita yang tidak terlalu panjang sehingga anak-anak tidak bosan dengan jalan ceritanya, buku kumpulan cerita anak muslim karya avan fathurrahman ini memiliki visualisasi yang menarik sehingga membuat anak-anak berimajinasi seperti mereka mengalami cerita tersebut. Dan ditambahkannya dengan cerita islami masa lalu memperkuat bahwa adanya nilai-nilai islami yang terkandung didalamnya.

Cerita merupakan salah satu cara untuk menanamkan nilai-nilai positif seperti merubah etika anak-anak, karena cerita bisa menarik anak-anak untuk menyukai dan memperhatikannya. mereka akan merekam semua doktrin, imajinasi, dan peristiwa yang ada dalam cerita tersebut.

Cerita merupakan media yang paling tepat untuk anak-anak dalam menanamkan nilai-nilai positif yang akan bermanfaat dalam kehidupannya di masa mendatang. Metode cerita juga menjadi hal yang sangat membantu dalam mempengaruhi psikis peserta didik. Karena di dalam cerita peserta didik tidak hanya mempengaruhi pikirannya tetapi emosinya juga. Di dalam suatu cerita pasti terdapat suatu unsur ide, pikiran, emosi, dan khayal. Karenanya cerita akan lebih terasa mendalam dan mengena bagi peserta didik apalagi jika peserta didik itu anak-anak.

Bercerita termasuk sebagai model pembelajaran berbasis masalah (Problem Based Learning) yang melibatkan siswa dalam pelaksanaannya. Sebagaimana Problem Based Learning memiliki arti Pembelajaran Berbasis Masalah yaitu jenis model pembelajaran yang melibatkan siswa dalam suatu kegiatan (proyek) untuk menghasilkan suatu produk. Keterlibatan siswa dimulai dari kegiatan merencanakan, membuat rancangan, melaksanakan, dan melaporkan hasil kegiatan berupa produk dan laporan pelaksanaanya. Model Pembelajaran ini lebih menekankan pada proses pembelajaran jangka panjang, siswa terlibat secara langsung dengan berbagai isu dan persoalan kehidupan sehari-hari, belajar bagaimana memahami dan menyelesaikan persoalan nyata, bersifat interdisipliner, dan melibatkan siswa sebagai pelaku utama dalam merancang, melaksanakan dan melaporkan hasil kegiatan (student centered).

Model pembelajaran ini sampai pada tahap operasi konkret anak mengenal sesuatu secara konkret dan alamiah. Piaget menyatakan bahwa anak mulai berpikir secara sistematis dan logis, namun pikirannya masih terikat pada objek-objek konkret dalam lingkungannya. Oleh karena itu, siswa perlu diberi kesempatan untuk memperkaya pengetahuannya tentang halhal konkret, urutan, logis, tetapi masih tergantung pada objek yang konkret. Termasuk kegiatan membaca buku cerita 
yang dilakukan peserta didik secara mandiri.

Anak-anak dan kita semua menyenangi cerita karena momen bercerita menghubungkan hati dan mendekatkan jiwa. Waktu yang didedikasikan khusus untuk bercerita menumbuhkan keintiman emosional. Setiap rumah dan sekolah perlu memiliki waktu khusus untuk bercerita.

\section{Metode Penelitian}

Metode penilitian yang digunakan dalam hal ini adalah metode kualitatif. Penulis tidak mengumpulkan data berupa angka-angka yang harus dianalisis sehingga bisa dijadikan patokan dalam penelitian.

Jenis penelitian ini, peneliti menggunakan Penelitian Kepustakaan (Library Research), yaitu penelitian yang mengumpulkan data dan informasi dengan bantuan bermacam-macam materi yang terdapat dalam kepustakaan (buku).

Untuk jenis pendekatan yang digunakan adalah pendekatan deskriptif eksploratif. Yaitu berusaha untuk mendeskripsikan, membahas dan menggali gagasan-gagasan pokok yang selanjutnya ditarik satu kasus baru.

Penelitian ini bersumber pada data primer yaitu buku kumpulan cerita anak muslim hebat karya avan fathurrahman dan data sekunder menggunakan literaturliteratur lain yang relevan dengan objek penelitian yaitu buku, jurnal, skripsi terdahulu, internet, dan lain-lain yang mempunyai pembahasan yang erat hubungannya dengan sumber primer.

Untuk mengelola hasil penelitian, maka dibutuhkan sebuah teknik analisa data yang tepat. Teknik analisis data merupakan cara menganalisis data penelitian, termasuk alat-alat statistik yang relevan untuk digunakan untuk penelitian. Adapun teknik analisa data yang digunakan penulis yaitu dengan teknik kajian isi (content analysis), yaitu yaitu teknik penelitian untuk membuat inferensi-inferensi yang dapat ditiru (replicable), dan shahi data dengan memperhatikan konteksnya. Jadi, teknik inilah yang digunakan untuk mendeskripsikan isi dari buku kumpulan cerita anak muslim hebat karya avan fathurrahman.

\section{Hasil Penelitian}

Nilai-Nilai Pendidikan Islam pada buku kumpulan cerita anak muslim hebat karya avan fathurrahman ini ditunjukkan dengan beberapa kisah di dalamya, dalam setiap kisah terdapat dialog antar tokoh dan juga deskripsi cerita, serta respon para tokoh lainnya. Banyak kisah yang ditunjukkan dengan percakapan yang ditulis sehingga mempermudah pembaca untuk mengulang kembali jika belum paham dengan apa yang disampaikan.

Sangat bermanfaat untuk pendidik mempermudah menyampaikan kepada peserta didik karena berupa kisah yang mudah juga untuk diperagakan. Untuk lebih jelas apa saja yang terkandung dalam beberapa kisah, penulis membagi dalam bentuk tabel berupa potongan dialog serta paragraf yang kemudian akan dikaitkan dengan ayat-ayat Al-Qur'an serta hadis terkait nilai-nilai pendidikan Islam dalam pembahasannya.

Adapun nilai-nilai pendidikan Agama Islam yang terdapat pada buku kumpulan cerita anak muslim hebat karya avan fathurrahman adalah sebagai berikut:

\section{Nilai-Nilai Pendidikan Aqidah dalam Buku Kumpulan Cerita Anak Muslim Hebat Karya Avan Fathurrahman}

\begin{tabular}{|l|l|l|}
\hline No & Dialog/ Paragraf & \multicolumn{1}{|c|}{$\begin{array}{c}\text { Nilai } \\
\text { Pendidikan }\end{array}$} \\
\hline 1. & $\begin{array}{l}\text { "Karena Allah } \\
\text { SWT akan } \\
\text { membalas } \\
\text { perbuatan baik, } \\
\text { sekecil apa pun } \\
\text { itu," kata Qonita. } \\
\text { (Percaya/ } \\
\text { Yakin } \\
\text { Kepada } \\
\text { Allah) }\end{array}$ \\
\hline 2. & $\begin{array}{l}\text { Rupanya Allah } \\
\text { SWT memberikan } \\
\text { balasan lebih baik } \\
\text { pada Dian. }\end{array}$ & $\begin{array}{l}\text { Nilai Aqidah } \\
\text { (Percaya/ } \\
\text { Yakin } \\
\text { Kepada } \\
\text { Allah) }\end{array}$ \\
\hline
\end{tabular}




\section{Nilai-Nilai Pendidikan Syariah/Ibadah dalam Buku Kumpulan Cerita Anak Muslim Hebat Karya Avan Fathurrahman}

\begin{tabular}{|c|c|c|}
\hline No & Dialog/ Paragraf & $\begin{array}{c}\text { Nilai } \\
\text { Pendidikan }\end{array}$ \\
\hline 1. & $\begin{array}{l}\text { "Sekarang, kamu } \\
\text { sholat dulu, ya, nak, } \\
\text { lalu makan." }\end{array}$ & $\begin{array}{l}\text { Nilai } \\
\text { Syariah/Ibadah } \\
\text { (Shalat) }\end{array}$ \\
\hline 2. & $\begin{array}{l}\text { Lalu pergi ke } \\
\text { mushala untuk } \\
\text { shalat. Dia tidak } \\
\text { pernah lalai menjaga } \\
\text { shalatnya. }\end{array}$ & $\begin{array}{l}\text { Nilai } \\
\text { Syariah/Ibadah } \\
\text { (Shalat) }\end{array}$ \\
\hline 3. & $\begin{array}{l}\text { "Anak-anak, seperti } \\
\text { biasa, sebelum } \\
\text { memulai pelajaran, } \\
\text { kita berdoa dulu, } \\
\text { ya," ujar bu Hanum }\end{array}$ & $\begin{array}{l}\text { Nilai } \\
\text { Syariah/Ibadah } \\
\text { (Berdoa) }\end{array}$ \\
\hline 4. & $\begin{array}{lr}\text { "Kalian } & \text { memang } \\
\text { anak-anak } & \text { yang } \\
\text { baik. Semoga } & \text { Allah } \\
\text { SWT } & \text { selalu } \\
\text { melimpahkan } & \\
\text { kebaikan } & \text { pada } \\
\text { kalian." } & \end{array}$ & $\begin{array}{l}\text { Nilai } \\
\text { Syariah/Ibadah } \\
\text { (Berdoa) }\end{array}$ \\
\hline 5. & $\begin{array}{l}\text { "Yuk, kita beri } \\
\text { makan Pusi. Setelah } \\
\text { itu, Kirana Ke } \\
\text { sekolah, ya, biar } \\
\text { semakin pintar," } \\
\text { ajak ibu }\end{array}$ & $\begin{array}{l}\text { Nilai } \\
\text { Syariah/Ibadah } \\
\text { (Menuntut } \\
\text { Ilmu) }\end{array}$ \\
\hline 6. & $\begin{array}{l}\text { Meski dari keluarga } \\
\text { sederhana, Samsul } \\
\text { bisa menunjukan } \\
\text { semangat belajar } \\
\text { yang tinggi. }\end{array}$ & $\begin{array}{l}\text { Nilai } \\
\text { Syariah/Ibadah } \\
\text { (Menuntut } \\
\text { Ilmu) (Berdoa) }\end{array}$ \\
\hline 7. & $\begin{array}{l}\text { "Nenek haus sekali, } \\
\text { Nak. Apakah boleh } \\
\text { Nenek meminta } \\
\text { segelas air minum?" } \\
\text { Tanya nenek itu. } \\
\text { "Oh tentu saja, Nek. } \\
\text { Ayo masuk dulu" } \\
\text { ajak Qonita. }\end{array}$ & $\begin{array}{l}\text { Nilai } \\
\text { Syariah/Ibadah } \\
\text { (Bersedekah) }\end{array}$ \\
\hline 8. & $\begin{array}{l}\text { "Assalamualaikum," } \\
\text { Ucap Zafira. } \\
\text { Waalaikumsalam, } \\
\text { Jawab Rena yang tak }\end{array}$ & $\begin{array}{l}\text { Nilai } \\
\text { Syariah/Ibadah } \\
\text { (Mengucap } \\
\text { Salam) }\end{array}$ \\
\hline
\end{tabular}

\begin{tabular}{|c|c|c|}
\hline & $\begin{array}{l}\text { lama kemudian } \\
\text { muncul dari balik } \\
\text { pintu rumahnya." }\end{array}$ & \\
\hline 9. & $\begin{array}{l}\text { "Assalamualaikum, } \\
\text { ucap Dian di depan } \\
\text { pintu. } \\
\text { Waalaikumsalam. } \\
\text { Halo keponakan } \\
\text { Tante yang cantik, } \\
\text { jawab seseorang." }\end{array}$ & $\begin{array}{l}\text { "Assalamualaik } \\
\text { um, ucap Dian } \\
\text { di depan pintu. } \\
\text { Waalaikumsala } \\
\text { m. Halo } \\
\text { keponakan } \\
\text { Tante yang } \\
\text { cantik, jawab } \\
\text { seseorang." }\end{array}$ \\
\hline
\end{tabular}

\section{Nilai-Nilai Pendidikan Syariah/Ibadah dalam Buku Kumpulan Cerita Anak Muslim Hebat Karya Avan Fathurrahman}

\begin{tabular}{|c|c|c|}
\hline No & Dialog/ Paragraf & $\begin{array}{c}\text { Nilai } \\
\text { Pendidikan }\end{array}$ \\
\hline 1. & $\begin{array}{l}\text { "Berbaik sangka } \\
\text { saja, yakinlah pusi } \\
\text { pulang. Biar nanti } \\
\text { Mbah Uti yang } \\
\text { bantu mencari, ya. } \\
\text { Sekarang Kirana } \\
\text { Sekolah Dulu," } \\
\text { bujuk Ibu. }\end{array}$ & $\begin{array}{l}\text { Nilai Akhlak } \\
\text { (Husnudzhan) }\end{array}$ \\
\hline 2. & $\begin{array}{l}\text { "Iya, sayang, } \\
\text { karena kirana } \\
\text { punya teman- } \\
\text { teman yang baik. } \\
\text { Makanya, Kirana } \\
\text { harus baik juga } \\
\text { sama mereka. Mau } \\
\text { bermain ramah, } \\
\text { selalu ceria, dan } \\
\text { saling membantu } \\
\text { dengan teman- } \\
\text { teman Kirana," } \\
\text { Ucap Ibu }\end{array}$ & $\begin{array}{l}\text { Nilai Akhlak } \\
\text { (Tolong } \\
\text { Menolong) }\end{array}$ \\
\hline 3. & $\begin{array}{l}\text { Sifat Naja yang } \\
\text { suka menolong } \\
\text { membuat Mahfi } \\
\text { mudah berteman } \\
\text { dengannya. }\end{array}$ & $\begin{array}{l}\text { Nilai Akhlak } \\
\text { (Tolong } \\
\text { Menolong) }\end{array}$ \\
\hline 4. & $\begin{array}{l}\text { Bagi Samsul, ini } \\
\text { adalah salah satu } \\
\text { cara } \\
\text { membantu }\end{array}$ & $\begin{array}{l}\text { Nilai Akhlak } \\
\text { (Berbakti } \\
\text { Kepada } \\
\text { Orangtua.) }\end{array}$ \\
\hline
\end{tabular}




\begin{tabular}{|c|c|c|}
\hline & $\begin{array}{l}\text { pekerjaan } \\
\text { orangtuanya. }\end{array}$ & \\
\hline 5. & $\begin{array}{l}\text { Lalu menyerahkan } \\
\text { uang } \\
\text { penjualan } \\
\text { gorengan. }\end{array}$ & $\begin{array}{l}\text { Nilai Akhlak } \\
\text { (Amanah) }\end{array}$ \\
\hline 6. & $\begin{array}{l}\text { Tak mau } \\
\text { mengecewakan } \\
\text { teman-temanya, } \\
\text { Dian pun } \\
\text { mengurungkan } \\
\text { niatnya membeli } \\
\text { buku dengan } \\
\text { meminjam uang } \\
\text { kas dan meletakan } \\
\text { kembali buku yang } \\
\text { diinginkannya itu. }\end{array}$ & $\begin{array}{l}\text { Nilai Akhlak } \\
\text { (Amanah) }\end{array}$ \\
\hline 7. & $\begin{array}{l}\text { Ibu pun menerima } \\
\text { uang tersebut } \\
\text { dengan penuh rasa } \\
\text { syukur. }\end{array}$ & $\begin{array}{l}\text { Nilai Akhlak } \\
\text { (Bersyukur) }\end{array}$ \\
\hline 8. & $\begin{array}{l}\text { "Iya. Mereka tadi } \\
\text { Cuma duduk- } \\
\text { duduk di bagian } \\
\text { utara taman ini, } \\
\text { kak. Nah, aku dan } \\
\text { Irul coba } \\
\text { mendekati, dan } \\
\text { ternyata beberapa } \\
\text { di antara mereka } \\
\text { adalah teman } \\
\text { sekolah kami. Jadi, } \\
\text { aku ajak, deh, ke } \\
\text { sini. Biar bisa } \\
\text { tambah } \\
\text { pengetahuan } \\
\text { bareng," jawab } \\
\text { Fika }\end{array}$ & $\begin{array}{l}\text { Nilai Akhlak } \\
\text { (Amar } \\
\text { Ma'ruf) }\end{array}$ \\
\hline 9. & $\begin{array}{l}\text { Mereka pun } \\
\text { menyadari dan } \\
\text { meminta maaf atas } \\
\text { kesalahan yang } \\
\text { mereka perbuat }\end{array}$ & $\begin{array}{l}\text { Nilai Akhlak } \\
\text { (meminta } \\
\text { maaf) }\end{array}$ \\
\hline 10 . & $\begin{array}{l}\text { "Tentu saja aku } \\
\text { akan } \\
\text { memaafkanmu, } \\
\text { Zafira." }\end{array}$ & $\begin{array}{l}\text { Nilai Akhlak } \\
\text { (Pemaaf) }\end{array}$ \\
\hline 11. & $\begin{array}{l}\text { "Sudah, jangan } \\
\text { menangis. Ibu } \\
\text { akan mengganti } \\
\text { uang Rena. Tapi, }\end{array}$ & $\begin{array}{l}\text { Nilai Akhlak } \\
\text { (Jujur) }\end{array}$ \\
\hline
\end{tabular}

\begin{tabular}{|l|l|l|}
\hline $\begin{array}{l}\text { kamu harus jujur } \\
\text { pada Rena, ya." }\end{array}$ & \\
\hline
\end{tabular}

Adapun penjabaran nilai-nilai Pendidikan Islam tersebut adalah sebagai berikut:

1. Nilai Pendidikan Keimanan/Aqidah Aqidah dalam bahasa Arab berasal dari kata "aqada, ya'qidu, aqiidatan" artinya ikatan atau sangkutan. Disebut demikian, karena ia mengikat dan menjadi sangkutan atau gantungan seluruh ajaran Islam. Menurut Aminuddin, aqidah bersifat mengajarkan keesaan Allah sebagai Tuhan yang mencipta, mengatur dan meniadakan alam ini.

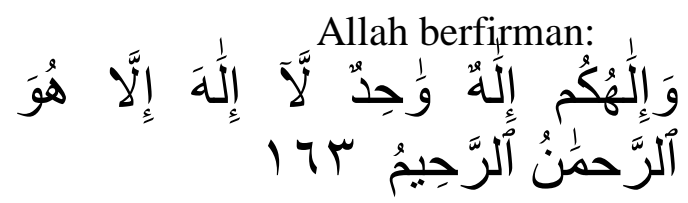

"Dan Tuhanmu adalah Tuhan Yang Maha Esa; tidak ada Tuhan melainkan Dia Yang Maha Pemurah lagi Maha Penyayang" (Q.S. Al-Baqarah/ 2:163).

Banyak cara yang dapat dilakukan untuk mewujudkan nilai-nilai pendidikan Islam tersebut, selain mengimani adanya Allah mengimani adanya ciptaan Allah baik Rasul, kitab yang diturunkan melalui nabi- nabinya, malaikat-malaikatnya, hari kiamat dan qodho qodarnya juga termasuk mewujudkan nilai-nilai pendidikan Islam yang hakiki. Berikut nilai-nilai pendidikan Islam dalam buku kumpulan cerita anak muslim hebat karya avan fathurrahman:

a. Iman/ Percaya Kepada Allah

Iman kepada Allah adalah mempercayai keesaan Allah melalui asmaul husna-Nya, sifat-sifatNya, serta mempercayai wujud-Nya. Beriman kepada Allah berarti meninggalkan segala bentuk penghambaan, dan tidak menyembah kepada selain Allah. Semua kegiatan yang dilakukan baik yang bersifat lahir maupun batin 
jasmaniyah maupun ruhaniyah semuanya ditujukan kepada Allah.

Iman/percaya kepada Allah bisa ditunjukan pula dengan sikap kita bahwa segala sesuatu yang kita kerjakan pastilah mendapat balasannya baik ataupun buruk karena kita yakin bahwa Allah yang maha segalanya.

Berikut potongan paragraf yang terdapat dalam buku kumpulan cerita anak muslim hebat karya avan fathurrahman yang menunjukan keyakinan seorang anak yang bernama Qonita bahwa Allah SWT akan membalas perbuatannya sekecil apapun itu.

"Karena Allah SWT akan membalas perbuatan baik, sekecil apa pun itu," kata Qonita.

Dari paragraf tersebut kita kaitkan dengan ayat Al-Quran yang menjelaskan segala sesuatu itu akan mendapatkan balasannya. Allah Berfirman:

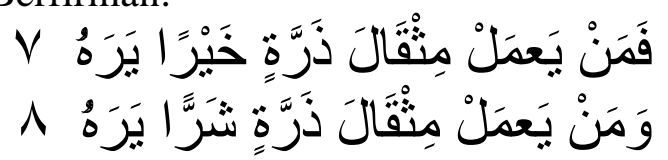

Barangsiapa yang mengerjakan kebaikan seberat dzarrahpun, niscaya dia akan melihat (balasan)nya.Dan barangsiapa yang mengerjakan kejahatan sebesar dzarrahpun, niscaya dia akan melihat (balasan)nya pula. (Q.S. Al-Zalzalah/ 99:7-8).

Dalam cerita ini Qonita bersama temannya yaitu Keysa yang sedang mau mengerjakan tugas prakaryanya tiba-tiba kedatangan seorang nenek tua yang ingin meminta segelas air putih, kemudian Qonita pun mempersilakannya masuk ke dalam rumah, akan tetapi Keysa yang kurang setuju mempertanyakan kepada Qonita kenapa Nenek itu diperbolehkan untuk masuk, tidak takutkah Qonita kalau nenek tersebut membawa penyakit, atau nenek tua itu hanya menyamar saja, heran Keysa. Namun Qonita yang membawa sepiring kue dan segelas air itu pun dengan hati yang mantap membalas ucapan Keysa dan percaya bahwa Allah pasti akan membalas perbuatan sekecil apapun itu.

Dan ini juga diperkuat dengan paragraf yang ada di cerita lainnya yaitu:

Rupanya Allah SWT memberikan balasan lebih baik pada Dian

Paragraf diatas menjelaskan kepada kita bahwa jika memang kita percaya kepada Allah, Niscaya Allah akan membalas kita dengan sesuatu yang lebih indah.

Cerita tentang seorang tokoh yang bernama Dian yang ingin sekali membeli buku cerita baru di toko buku, namun ia tidak mempunyai cukup uang untuk membeli buku tersebut, pernah terbesit dipikirannya untuk meminjam uang kas kelas, karena memang kebetulan ia menjabat sebagai bendahara kelas. Namun dengan keyakinannya pula kepada Allah dan takut untuk kehilangan kepercayaan teman-temannya ia pun mengurungkan niatnya untuk meminjam uang kas terlebih dahulu. Dan benar, ketika ia pulang ke rumah, tiba-tiba Tantenya sudah datang dan telah membelikannya buku cerita yang baru.

Dari cerita ini kita bisa mengambil pelajaran berharga bahwa keyakinan kepada Allah itu sangat penting dan harus ditanamkan pada peserta didik.

2. Nilai Pendidikan Ibadah/Syariah

Ibadah adalah suatu wujud perbuatan yang dilandasi rasa pengabdian kepada Allah SWT. Ibadah yaitu perbuatan yang menyatakan bakti kepada Allah Swt.

Di dalam buku kumpulan cerita anak muslim hebat karya avan fathurrahman terdapat nilai-nilai pendidikan ibadah/syariah diantaranya: shalat, berdoa, bersedekah, dan mengucap salam.

a. Shalat

Shalat, secara etimologis, berarti doa. Adapun shalat, secara terminologis, adalah seperangkat perkataan dan perbuatan yang dilakukan dengan beberapa syarat 
tertentu, dimulai dengan takbir dan diakhiri dengan salam. Pengertian shalat ini mencakup segala bentuk shalat yang diawali dengan takbirat al-ihram dan diakhiri dengan salam. Allah berfirman:

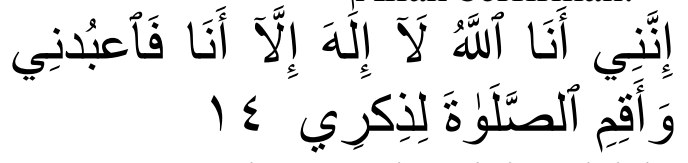

"Sesungguhnya Aku ini adalah Allah, tidak ada Tuhan (yang hak) selain Aku, maka sembahlah Aku dan dirikanlah shalat untuk mengingat Aku." (Q.S. Ta ha/ 20:14).

Dalam buku kumpulan cerita anak muslim hebat karya avan fathurrahman nilai pendidikan syariah/ ibadah shalat ini terdapat pada paragraf:

"Sekarang, kamu sholat dulu, ya, nak, lalu makan"

Diceritakan bahwa Samsul adalah seorang anak yang tinggal bersama ibunya. Setiap hari ia berangkat ke sekolah sambil mengantarkan gorengan buatan ibunya untuk di jual di warung Bi Sumi. Tokoh Samsul di ceritakan seorang yang sederhana, ia anak yang amanah, berbakti kepada orangtua, rajin belajar dan juga tidak pernah lalai menjaga shalatnya. Ini dibuktikan dalam paragraf selanjutnya yaitu:

"Lalu pergi ke mushala untuk shalat. Dia tidak pernah lalai menjaga shalatnya".

Dalam cerita tersebut Samsul selalu menjaga shalatnya dan tidak pernah lalai meninggalkannya. Sebagaimana firman Allah:

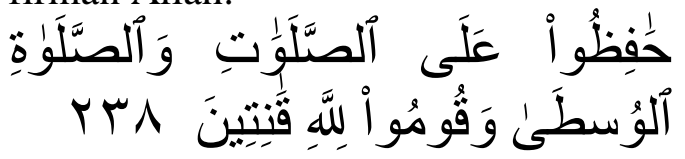

"Peliharalah semua shalat(mu), dan (peliharalah) shalat wusthaa. Berdirilah untuk Allah (dalam shalatmu) dengan khusyu'.” (Q.S. Al-Baqarah/ 2:238).

Dalam islam, shalat merupkan suatu kewajiban yang harus dikerjakan oleh setiap muslim/muslimah, shalat juga merupaka tiang agama. Sebagaimana sabda Nabi:

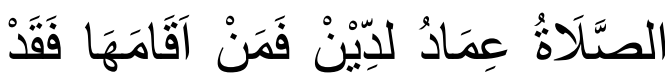

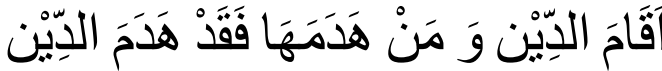

"Shalat itu adalah tiang agama, maka barang siapa mendirikanya, sungguh ia telah menegakan agama itu, dan barang siapa merobohkannya, sungguh ia telah merobohkan aga itu" (H.R. Al-Baihaqi).

Maka dari itu, pelajaran yang berharga dapat kita ambil dari kisah Samsul ini, dan terutama untuk anakanak.

\section{b. Berdoa}

Berdo'a artinya mengajukan permohonan kepada Allah. Berdo'a merupakan bukti pengakuan kita terhadap kekuasaan Allah, karena dengan kekuasaan dan bantuan-Nya lah semua permintaan dan kebutuhan bisa terpenuhi. Apabila meminta kepada manusia, semakin banyak permintaan kita kepada orang itu semakin keberatan ia, bahkan bisa jadi menolak. Berbeda dengan meminta dan memohon kepada Allah, pasti Allah akan kabulkan doa kita. Sebagaimana firman Allah:

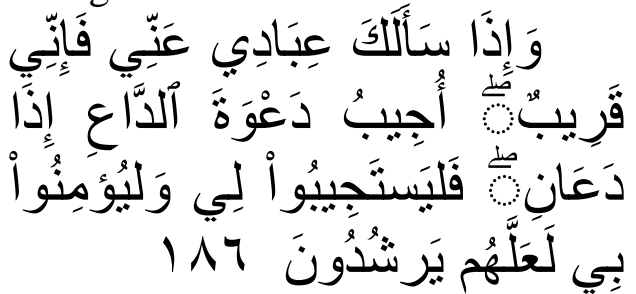

"Dan apabila hamba-hamba-Ku bertanya kepadamu tentang Aku, maka (jawablah), bahwasanya Aku adalah dekat. Aku mengabulkan permohonan orang yang berdoa apabila ia memohon kepada-Ku, maka hendaklah mereka itu memenuhi (segala perintah-Ku) dan hendaklah mereka beriman kepada$\mathrm{Ku}$, agar mereka selalu berada dalam kebenaran." (Q.S. Al-Baqarah/ 2: 186).

Dalam buku kumpulan cerita anak muslim hebat karya avan fathurrahman nilai pendidikan syariah/ ibadah yaitu berdoa terdapat pada paragraf: 
"Anak-anak, seperti biasa, sebelum memulai pelajaran, kita berdoa dulu, ya," ujar bu Hanum.

Dalam cerita tersebut, digambarkan 3 orang anak yang akan melakukan bolos sekolah karena mereka tidak suka dengan pelajaran matematika, namun, rencana mereka itu gagal. Bu Hanum sebagai Guru matematika seperti biasanya ketika akan mulai pelajaran selalu berdoa terlebih dahulu.

Tentu kebiasaan ini perlu ditanamkan kepada peserta didik, dan hal ini juga mengindikasikan bahwa dalam cerita tersebut ada nilai pendidikan Syariah/Ibadah yaitu berdoa.

Dalam cerita lain juga terdapat hal serupa, yaitu dalam paragraf:

"Kalian memang anak-anak yang baik. Semoga Allah SWT selalu melimpahkan kebaikan pada kalian"

Paragraf diatas menunjukan bahwa seorang Nenek tua yang mendoakan kebaikan kepada Qonita dan Keysa, karena telah memberikan kepadanya sepiring kue dan segelas air minum.

Nabi Muhammad Saw menegaskan tentang berdoa yang harus menjadi kewajiban bagi umat manusia, karena berdoa adalah sebuah kebutuhan yang ditujukan kepada Allah,

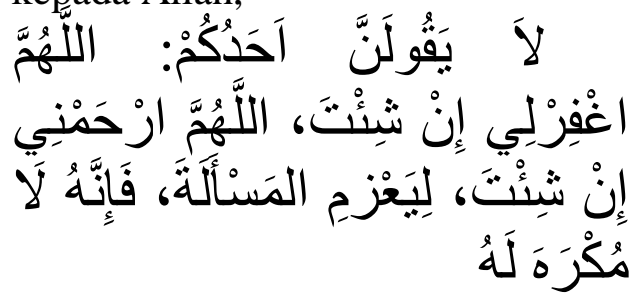

"Janganlah sekali-kali salah seorang di antara kamu berkata, "Ya Allah, ampunilah aku jika Engkau menghendaki. Ya Allah, sayangilah aku jika Engkau menghendaki. Hendaklah ia serius meminta, karena tidak ada yang memaksa-Nya." (HR. Bukhari dan Muslim).

c. Bersedekah
Definisi sedekah adalah pemberian seorang muslim kepada orang lain secara sukarela dan ikhlas tanpa dibatasi oleh waktu dan jumlah tertentu. Sedekah lebih luas dari sekedar zakat maupun infak. Karena sedekah tidak hanya berarti mengeluarkan atau menyumbangkan harta. Namun mencakup segala amal atau perbuatan baik. Allah telah berfirman dalam surat Al-qur'an berikut:

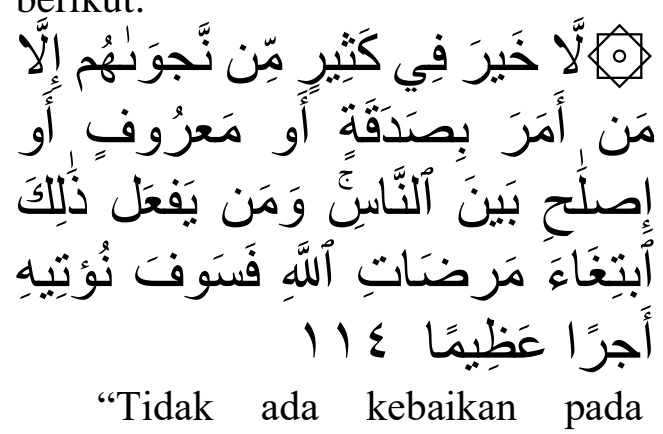
kebanyakan bisikan-bisikan mereka, kecuali bisikan-bisikan dari orang yang menyuruh (manusia) memberi sedekah, atau berbuat ma'ruf, atau mengadakan perdamaian di antara manusia. Dan barangsiapa yang berbuat demikian karena mencari keridhaan Allah, maka kelak Kami memberi kepadanya pahala yang besar". (Q.S. An-Nisa/ 4: 114).

Dalam buku kumpulan cerita anak muslim hebat karya avan fathurrahman nilai pendidikan syariah/ ibadah yaitu bersedekah terdapat pada paragraf:

"Nenek haus sekali, Nak. Apakah boleh Nenek meminta segelas air minum?" Tanya nenek itu. "Oh tentu saja, Nek. Ayo masuk dulu" ajak Qonita.

Pada potongan dialog diatas memang tidak secara jelas menunjukan kepada sedekah, namun dari dialog tersebut kita bisa mengambil makna sedekah, sebagaimana definisi sedekah yaitu pemberian seorang muslim kepada orang lain secara sukarela dan ikhlas tanpa dibatasi oleh waktu dan jumlah tertentu. 
Ketika sang Nenenk meminta air, Qonita dengan senang hati menjawab "Oh tentu" berarti memang ia secara sukarela dan ikhlas memberikannya kepada sang Nenek, bahkan tidak hanya segelas air, Qonita pun memberikan sepiring kue untuk nenek tersebut, walaupun tidak seberapa, tapi ada nilai sedekah yang dapat kita ambil.

Cerita ini menunjukkan bahwa sedekah merupakan hal yang mulia dan memberikan rasa senang bagi orang yang menerima sedekah tersebut. Orang yang bersedekah tidak akan berkurang hartanya, bahkan harta itu akan menjadi berkah. Dalam hadist Nabi Bersabda:

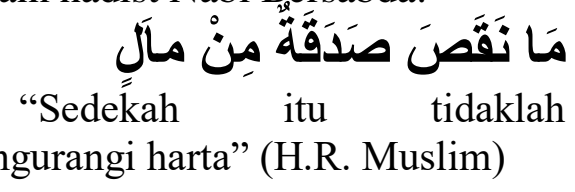

\section{d. Menuntut Ilmu \\ Menuntut ilmu merupakan kewajiban bagi seorang} muslim/muslimah, jika seseorang ingin bahagia dunia dan akhirat hendaklah ia memiliki ilmu, sebagaimana dalam hadist:

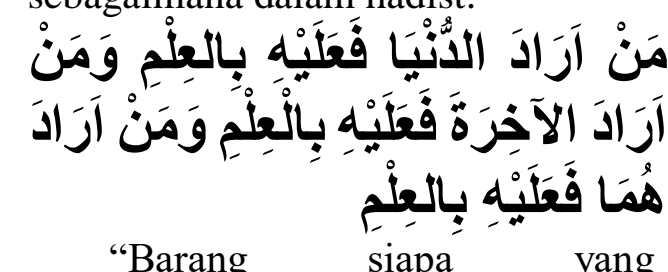

menghendaki kehidupan di dunia maka wajib baginya memiliki ilmu, dan barang siapa yang ingin menghendaki kehidupan di akhirat maka wajib baginya memiliki ilmu, dan barang siapa yang menghendaki keduanya maka wajib baginya memiliki ilmu." (H.R Turmudzi)

Dalam buku kumpulan cerita anak muslim hebat karya avan fathurrahman paragraf yang mengindikasikan bahwa ada nilai tentang menuntut ilmu yaitu:

"Yuk, kita beri makan Pusi. Setelah itu, Kirana Ke sekolah, ya, biar semakin pintar," ajak ibu.
Tokoh Kirana yang kehilangan kucingnya dan tidak mau pergi ke sekolah jika tidak menemukan kucingnya itu merupakan contoh yang lumrah di kalangan anak-anak. Tapi karena bimbingan dan bujukan dari orang tua, terutama Ibu akhirnya Kirana bersedia untuk pergi sekolah, dan sekolah merupakan salah satu tempat untuk menuntut ilmu.

Ataupun, menuntut ilmu bisa juga dibuktikan dengan kesungguhan seseorang yang ingin menuntut ilmu/ semangat dalam menuntut ilmu, seperti pada paragraf:

Meski dari keluarga sederhana, Samsul bisa menunjukan semangat belajar yang tinggi.

Semangat belajar juga perlu kita tanamkan kepada peserta didik, dengan begitu mereka akan terus belajar dan belajar, sehingga kelak bisa menjadi seseorang yang akan memberi peringatan kepada kaumnya, Allah berfirman:

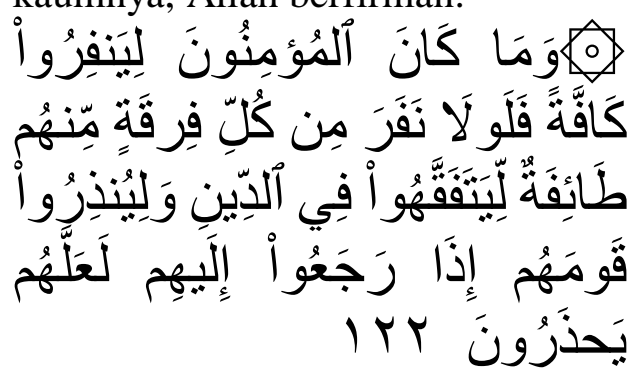

"Tidak sepatutnya bagi mukminin itu pergi semuanya (ke medan perang). Mengapa tidak pergi dari tiap-tiap golongan di antara mereka beberapa orang untuk memperdalam pengetahuan mereka tentang agama dan untuk memberi peringatan kepada kaumnya apabila mereka telah kembali kepadanya, supaya mereka itu dapat menjaga dirinya." (Q.S. At-Taubah/ 9:122).

Selain itu, Allah akan mengangkat derajat orang yang menuntut ilmu lagi beriman. Allah berfirman:

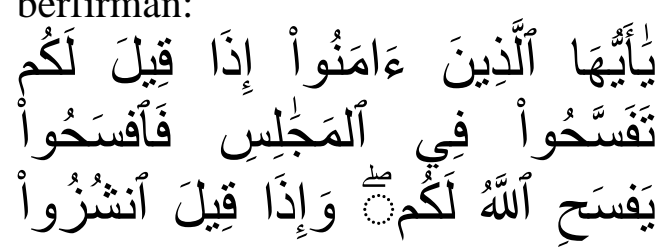




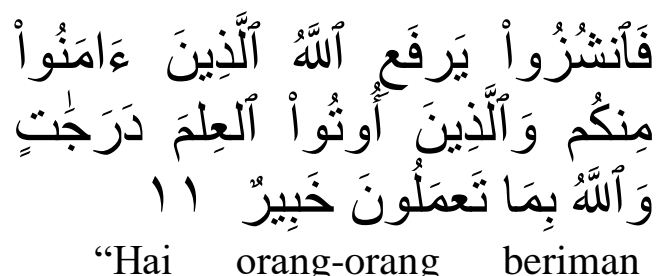
apabila dikatakan kepadamu: "Berlapang-lapanglah dalam majlis", maka lapangkanlah niscaya Allah akan memberi kelapangan untukmu. Dan apabila dikatakan: "Berdirilah kamu", maka berdirilah, niscaya Allah akan meninggikan orang-orang yang beriman di antaramu dan orangorang yang diberi ilmu pengetahuan beberapa derajat. Dan Allah Maha Mengetahui apa yang kamu kerjakan." (Q.S. Al-Mujadilah/ 58 : 11).

Maka dari itu, sepatutnya kita harus semangat dalam menuntut ilmu, dan untuk orang tua, agar senantiasa membimbing anaknya agar kelak menjadi orang yang berilmu.

\section{Nilai Pendidikan Akhlak}

\section{a. Husnudzhan}

Husnudhzan (berperasangkan baik) adalah meyakini Asma', sifat serta perbuatan Allah SWT yang layak bagi-Nya. Sebuah keyakinan yang menuntut pengaruh yang nyata. Misalnya, meyakini bahwa Allah merahmati semua hamba-Nya dan memaafkan mereka jika mereka bertaubat dan kembali kepada-Nya.

Allah berfirman:

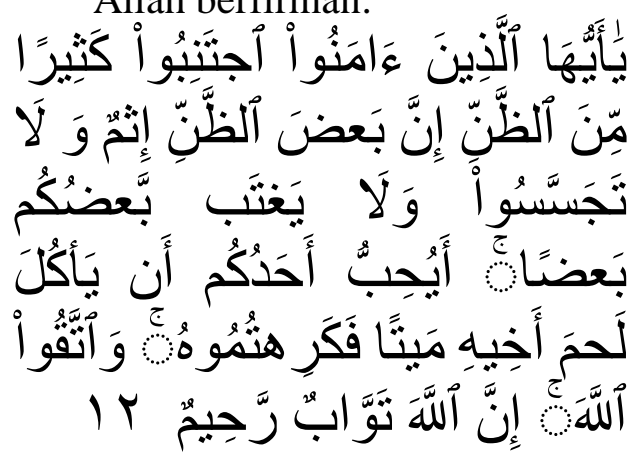

"Hai orang-orang yang beriman, jauhilah kebanyakan purba-sangka (kecurigaan), karena sebagian dari purba-sangka itu dosa. Dan janganlah mencari-cari keburukan orang dan janganlah menggunjingkan satu sama lain. Adakah seorang diantara kamu yang suka memakan daging saudaranya yang sudah mati? Maka tentulah kamu merasa jijik kepadanya. Dan bertakwalah kepada Allah. Sesungguhnya Allah Maha Penerima Taubat lagi Maha Penyayang." (Q.S. Al Hujurat/ 49:12).

Adapun Konteks dalam buku kumpulan cerita anak muslim hebat karya avan fathurrahman ini yang mengandung Nilai Husnudzhan adalah:

"Berbaik sangka saja, yakinlah pusi pulang. Biar nanti Mbah Uti yang bantu mencari, ya. Sekarang Kirana Sekolah Dulu," bujuk Ibu.

Kita harus berbaik sangka/ husnudzhan dalam kekhawatiran. Cerita tentang kucing Kirana yang hilang salah satu contohnya. Dan baiknya orangtua harus menenangkan kepanikan yang dialami oleh anaknya.

\section{b. Tolong Menolong}

Tolong menolong merupakan sikap untuk saling membantu, tolong menolong disini maksudnya adalah dalam hal kebaikan dan bukan tolong menolong dalam hal keburukan, Allah berfirman:

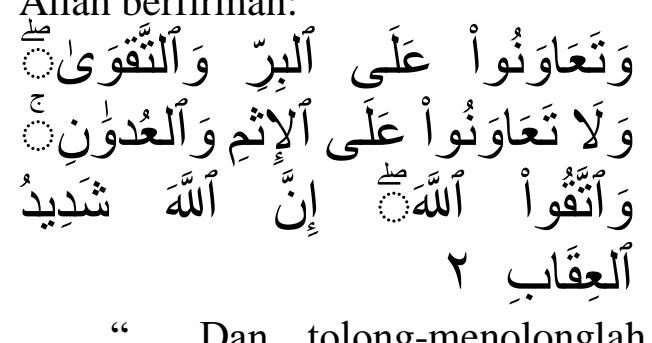

“... Dan tolong-menolonglah kamu dalam (mengerjakan) kebajikan dan takwa, dan jangan tolongmenolong dalam berbuat dosa dan pelanggaran. Dan bertakwalah kamu kepada Allah, sesungguhnya Allah amat berat siksa-Nya." (Q.S. AlMaidah/ $5: 2$ ).

Adapun kutipan dalam buku kumpulan cerita anak muslim hebat karya avan fathurrahman adalah:

"Iya, sayang, karena kirana punya teman-teman yang baik. Makanya, Kirana harus baik juga 
sama mereka. Mau bermain ramah, selalu ceria, dan saling membantu dengan teman-teman Kirana," Ucap Ibu.

Seorang Ibu yang membimbing anaknya agar selalu berteman baik, dan juga harus saling tolong menolong, tentunya hal ini perlu ditanamkan kepada anak-anak.

Adapun kutipan lainnya terkait tolong menolong yaitu:

Sifat Naja yang suka menolong membuat Mahfi mudah berteman dengannya.

Kalimat diatas menunjukan kejadian yang sering terjadi dalam kehidupan anak-anak. Terutama di sekolah. Ketika salahsatu temannya yang tidak membawa pensil, dan tidak bisa menulis pelajaran karenanya, maka dari itu tokoh Naja yang datang kemudian meminjamkan pensil/ alat tulisnya sehingga ia mudah berteman dengan siapapun. Dan ini semua karena salah satu sifatnya yaitu suka menolong.

\section{c. Berbakti Kepada Orangtua}

Berbakti kepada orangtua merupakan salahsatu sifat terpuji nan mulia. Karena merekalah sebab kita berada di dunia ini, dan kita diwajibkan berbakti kepadanya.

Allah berfirman:

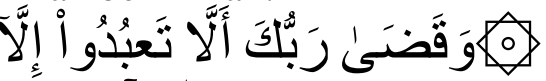

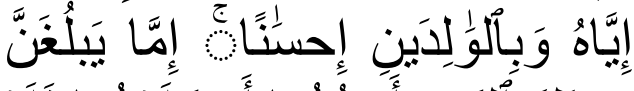

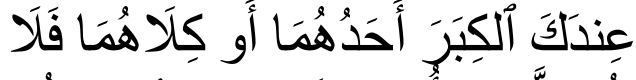

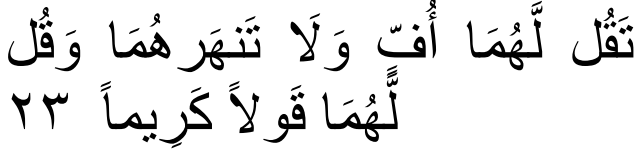

"Dan

Tuhanmu

telah

memerintahkan supaya kamu jangan menyembah selain Dia dan hendaklah kamu berbuat baik pada ibu bapakmu dengan sebaik-baiknya. Jika salah seorang di antara keduanya atau kedua-duanya sampai berumur lanjut dalam pemeliharaanmu, maka sekalikali janganlah kamu mengatakan kepada keduanya perkataan "ah" dan janganlah kamu membentak mereka dan ucapkanlah kepada mereka perkataan yang mulia. (Q.S. Al-Isra/ 17:23).

Adapun kutipan dalam buku kumpulan cerita adalah:

Bagi Samsul, ini adalah salah satu cara untuk membantu pekerjaan orangtuanya.

Membantu pekerjaan orang tua merupakan salahsatu contoh kita berbakti kepada mereka. Sebagaimana firman Allah diatas yang menjelaskan berkata "ah" saja tidak boleh. Apalagi lebih dari itu. Dengan kita membantu pekerjaan orangtua, tentunya kita sudah mengurangi bebannya.

\section{d. Amanah}

Amanah yaitu menjaga apa yang telah dipecayakan kepada kita. Jangan sampai kita yang diberikan amanah mengecewakan orang yang telah mempercayai kita.

Dalam kutipan buku kumpulan cerita anak muslim hebat, nilai amanah ini bisa kita baca dalam paragraf:

Tak mau mengecewakan temantemanya, Dian pun mengurungkan niatnya membeli buku dengan meminjam uang kas dan meletakan kembali buku yang diinginkannya itu.

Sosok Dian dalam cerita tersebut adalah seorang yang diamanahkan menjadi bendahara kelas. Walaupun ia ingin sekali membeli buku cerita itu, tapi ia mengurungkan niatnya untuk tidak memakai uang kelas, walaupun itu sifatnya meminjam.

Inilah contoh gambaran agar kita senantiasa menjaga amanah dan tidak mengecewakan orang yang telah percaya kepada kita.

Allah berfirman:

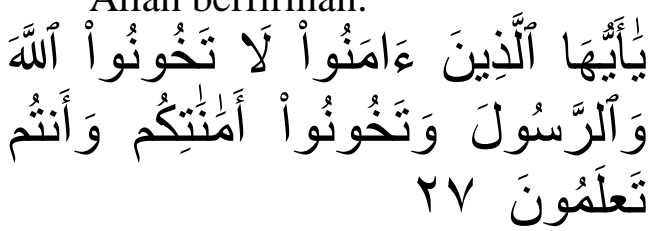


"Hai orang-orang yang beriman, janganlah kamu mengkhianati Allah dan Rasul (Muhammad) dan (juga) janganlah kamu mengkhianati amanat-amanat yang dipercayakan kepadamu, sedang kamu mengetahui." (Q.S. Al-Anfal/ 8:27).

\section{e. Bersyukur}

Syukur adalah merasa gembira atas pemberian dan karunia-Nya, menyatakan kegembiraan itu dengan ucapan dan perbuatan, memelihara dan mengunakan karunia itu sesuai dengan kehendakNya.

Adapun kutipan dalam buku kumpulan cerita anak muslim adalah:

Ibu pun menerima uang tersebut dengan penuh rasa syukur

Seorang Ibu yang tinggal bersama anaknya yaitu Samsul dan hidup dalam kesederhanaan merupakan salahsatu contoh dikehidupan kita. Terkadang banyak orang yang tidak mengerti arti dari kata bersyukur. Apapun yang kita terima itulah yang terbaik yang Allah berikan kepada kita. Walaupun hanya sebatas penjual gorengan, namun Ibu Samsul tetap mensyukuri apa yang telah diberikan kepadanya.

Allah berfirman:

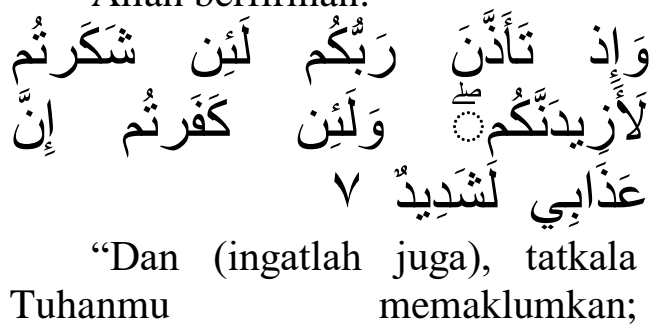

Sesungguhnya jika kamu bersyukur, pasti Kami akan menambah (nikmat) kepadamu, dan jika kamu mengingkari (nikmat-Ku), maka sesungguhnya azab-Ku sangat pedih". (Q.S. Ibrahim/ 14:7).

Dari ayat diatas kita dapat mengambil kesimpulan bahwa jika kita bersyukur maka Allah akan menambah nikmat kita. Dan sebaliknya jika kita ingkar, maka azab-Nya sangat pedih.

\section{f. Amar Ma'ruf}

Dalam islam, kita dianjurkan untuk berbuat baik dan mengajak kepada kebaikan itulah Amar Ma'ruf. Allah berfirman dalam Al-Quran:

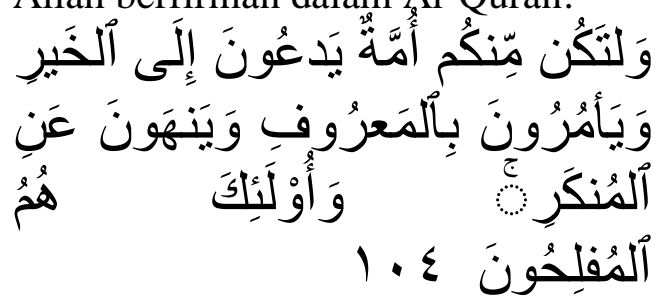

Dan hendaklah ada di antara kamu segolongan umat yang menyeru kepada kebajikan, menyuruh kepada yang ma'ruf dan mencegah dari yang munkar; merekalah orang-orang yang beruntung. (Q.S. Al-Imran/ 3: 104).

Adapun kutipan dalam buku kumpulan cerita anak muslim hebat adalah:

"Iya. Mereka tadi Cuma dudukduduk di bagian utara taman ini, kak. $\mathrm{Nah}$, aku dan Irul coba mendekati, dan ternyata beberapa di antara mereka adalah teman sekolah kami. Jadi, aku ajak, deh, ke sini. Biar bisa tambah pengetahuan bareng," jawab Fika.

Fika mengajak teman-temannya yang sedang duduk untuk ikut bersama ke perpustakaan keliling pak tomo, dengan harapan mereka bisa menambah ilmu pengetahuan dengan membaca buku-buku di perpustakaan keliling tersebut.

Tentu sikap Fika perlu kita contoh, mengingat kurangnya minat baca/literasi sejak dini, khususnya di Indonesia. Anak-anak tidak sedikit menggunakan teknologi untuk hiburan semata.

Dengan kita mengajak kepada kebaikan, kita juga akan mendapatkan pahala dari orang yang kita ajak tersebut. Dalam hadist pun dikatakan:

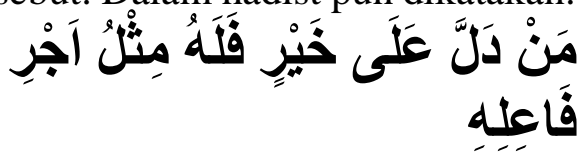


"Barang siapa menunjukan kepada kebaikan, maka ia memperoleh pahala seperti pahala orang yang melakukannya" (H.R. Muslim).

\section{g. Meminta Maaf/ Pemaaf}

Meminta maaf adalah sikap seseorang ketika mengetahui kesalah, sedangkan Pemaaf adalah sikap memaafkan ketika seseorang berbuat kesalahan kepadanya. Allah SWT menjanjikan surga bagi orang yang pemaaf. Allah berfirman:

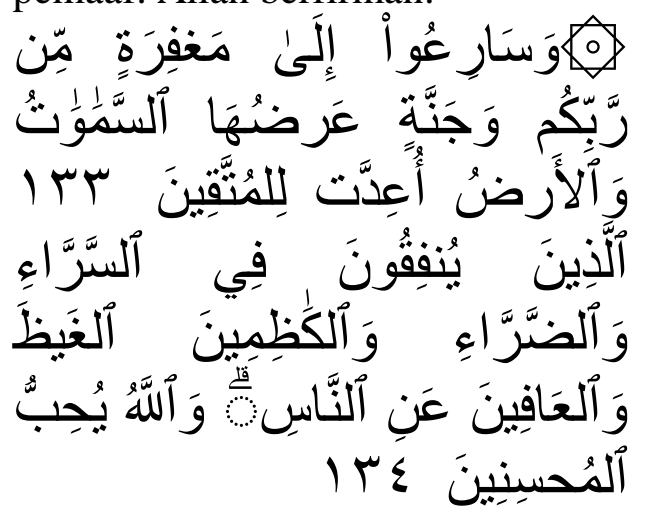

"Dan bersegeralah kamu kepada ampunan dari Tuhanmu dan kepada surga yang luasnya seluas langit dan bumi yang disediakan untuk orangorang yang bertakwa; (yaitu) orangorang yang menafkahkan (hartanya), baik di waktu lapang maupun sempit, dan orang-orang yang menahan amarahnya dan memaafkan (kesalahan) orang. Allah menyukai orang-orang yang berbuat kebajikan." (Q.S. Al-Imran/ 3 : 133-134).

Adapun kutipan dalam buku kumpulan cerita anak muslim hebat yang menunjukan pada nilai meminta maaf dan pemaaf yaitu:

Mereka pun menyadari dan meminta maaf atas kesalahan yang mereka perbuat.

Perlu keberanian untuk kita bisa meminta maaf, terutama anak-anak. Terkadang mereka mengetahui perbuatan itu salah, tapi enggan untuk meminta maaf lantaran takut. Dalam kutipan kalimat diatas merupakan contoh jika memang kita melakukan kesalahan, segeralah meminta maaf.
Sedangkan paragraf:

"Tentu saja aku akan memaafkanmu, Zafira.

Adalah bukti ketika kita sudah berani untuk meminta maaf, maka jadilah kita pemaaf, niscaya orang yang meminta maaf pun akan baik pula kepada kita.

Sikap meminta maaf dan pemaaf harus terus dikembangkan oleh setiap peserta didik, agar nantinya mereka menjadi pribadi yang baik.

\section{h. Jujur}

Dalam bahasa Arab berasal dari kata "Ash-Shiddiq" adalah orang yang selalu bersikap jujur dalam perkataan dan perbuatan. Jujur dapat diartikan sebagai kehati-hatian seseorang dalam memegang amanah yang telah dipercayakan oleh orang lain. Kejujuran tergolong akhlak terpuji. Seseorang dikatakan jujur bila menyatakan kebenaran sesuai dengan fakta yang ada. Sesungguhnya kejujuran itu tanda dari kebaikan.

Adapun kutipan dalam buku kumpulan cerita anak muslim adalah:

"Sudah, jangan menangis. Ibu akan mengganti uang Rena. Tapi, kamu harus jujur pada Rena, ya.

Dalam dialog diatas, kita sebagai orang tua harus bisa meyakinkan anak-anak untuk berlaku jujur. Ditengah kebingungan ia harus berbuat apa, dan tidak berani untuk mengungkapkanya, disitulah peran kita untuk senantiasa membimbingnya.

Sikap jujur perlu dimiliki oleh setiap peserta didik, karena kejujuran merupakan suatu yang penting dan perlu ditanamkan sejak dini.

Allah berfirman:

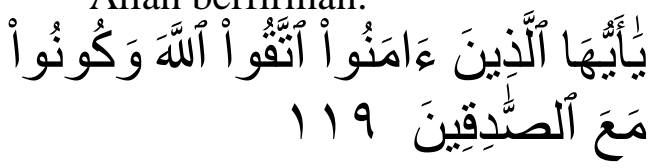

"Hai orang-orang yang beriman bertakwalah kepada Allah, dan hendaklah kamu bersama orangorang yang benar." (Q.S. At-Taubah/ $9: 119)$. 
Sebagaimana telah disebutkan diatas, kata "Ash-Shiddiq" merupakan orang yang jujur dalam perkataan dan perbuatan, sudah sepatutnya kita orang yang beriman dan bertaqwa untuk berlaku jujur

Begitupun sebagaimana harapan orangtua kepada anaknya agar menjadi pribadi yang baik, yaitu taat kepada Allah, memiliki sikap jujur, amanah, dan juga menjadi sosok yang berpengaruh di lingkungannya dan bahkan negaranya, aspek-aspek seperti nilai-nilai diatas perlulah kita mengetahui bahwa nilai-nilai tersebut ada pada pendidikan islam, lalu kita terapkan dalam proses pembelajaran itu sangatlah relevan.

Ada beberapa metode dalam pendidikan islam, salah satunya adalah metode melalui kisah-kisah/cerita. Disini, penulis menggabungkan antara cerita-cerita yang ada pada buku kumpulan cerita anak muslim hebat karya avan fathurrahman dengan pendidikan masa kini yang mempengaruhi karakter setiap peserta didik menjadi lebih baik. Melalui kisah-kisah yang terdapat dalam buku cerita karya avan fathurrahman tersebut, diharapkan nilainilai pendidikan tersalurkan dengan baik tanpa ada paksaaan.

Materi pendidikan islam yang terdapat dalam buku kumpulan cerita anak muslim hebat karya avan fathurrahman mengupas tentang pendidikan aqidah/keimanan, yang didalamnya ada pembelajaran tentang percaya kepada Allah SWT.

Pendidikan Syariah/Ibadah seperti melaksanakan shalat, berdoa, bersedekah, menuntut ilmu. Kemudian Pendidikan Akhlak seperti husnudzhan, saling tolong menolong, berbakti kepada orangrua, amanah bersyukur, Amar Ma'ruf, pemaaf, dan jujur.

Dengan demikian, nilai-nilai pendikan islam yang terdapat pada buku ini dapat dijadikan materi pendidikan islam.

\section{Kesimpulan}

Setelah penulis melakukan penelitan terhadap buku kumpulan cerita anak muslim hebat karya avan fathurrahman ini, dengan kajian berupa nilai-nilai pendidikan islam maka penulis mengambil kesimpulan sebagai berikut:

1. Nilai-nilai pendidikan islam yang terdapat pada buku kumpulan cerita anak muslim hebat karya avan fathurrahman adalah: Nilai pendidikan aqidah/ keimanan yaitu (keimanan kepada Allah), nilai pendidikan syariah/ibadah yaitu (shalat, berdoa, bersedekah, menuntut ilmu), nilai pendidikan akhlak yaitu (husnudzhan, tolong menolong, berbakti kepada orangtua, amanah, bersyukur, amar ma'ruf, meminta maaf/pemaaf, dan jujur).

2. Relevansi nilai -nilai pendidikan islam yang terdapat pada buku kumpulan cerita anak muslim hebat karya avan fathurrahman dengan pendidikan dewasa ini yaitu: nilainilai sangat relevan dengan hal apapun dilihat dari segala aspek.

\section{Saran}

Apa yang penulis paparkan tentu dapat menyadarkan para orang tua untuk memberikan pendidikan islam sedini mungkin kepada anak, mengingat keluarga adalah lingkungan terdekat dengan anak dan orangtua menjadi madrasah pertama bagi anak.

Dan tentunya, dalam dunia pendidikan bisa mengembangkan metode pembelajaran lebih kreatif lagi, dengan memanfaatkan teknologi zaman sekarang seperti audio visual ataupun kisah-kisah yang lebih membekas lama pada peserta didik.

Dan juga lebih mengutamakan karya sastra berisi lebih banyak makna nilai-nilai yang dapat diambil, sehingga bisa menjadi pelajaran berharga bagi pembaca dalam kehidupan sehari-hari, dan menarik pembaca untuk usia sedini mungkin sehingga memperbanyak minat di usia muda.

\section{Daftar Pustaka}


Abdul Majid, Abdul Aziz. Mendidik Dengan Cerita. Bandung: PT Rosda Karya. 2002.

Arikunto. Manajemen Penelitian. Jakarta: Rineka Cipta. 1995.

Baker. Metode-Metode Penelitian Filsafat. Yogyakarta: Kanisius. 1986.

Marbun, Firly Hakiki. Alia Azmi. "Perilaku Imitasi Komunitas Penggemar KPop di Kota Padang". Journal of Civic Education (ISSN: 2622-237X) Volume 2. No. 4. tahun 2019.

Hadi. Metodologi Research. Yogyakarta: Andi Offset. 2000.

Hartinah, Sri. Metode Penelitian Perpustakaan. Tangerang Selatan: Universitas Terbuka. 2014.

Muhadjir, Noeng. Metode Penelitian Kualitatif. Jakarta: Grasindo. 1996.

Rohman, Mujibur. "Problematika Kurikulum Pendidikan Islam". Jurnal Madaniyah. Edisi VIII. tahun 2015.

Moleong, Lexy J. Metodologi Penelitian Kualitatif. Bandung: PT. Remaja Rosdakarya. 2016.

Noor, Juliansyah. Metodologi Penelitian: Skripsi, Tesis, Disertasi, dan Karya Ilmiyah. Jakarta: Kencana Prenada Media Group. 2011.

Ramayulis. Ilmu Pendidikan Islam. Jakarta: Kalam Mulia. 2002.

Sumarianto. "Analisis Buku Ajar Pendidikan Agama Islam Dalam Perspektif Badan Standar Nasional Pendidikan (Telaah Buku Pendidikan Agama Islam Kelas VI Sekolah Dasar Penerbit Dewan Pengurus Pusat Hidayatullah dan Erlangga)." Thesis. Surabaya: Pascasarjana Universitas Islam Negeri Sunan Ampel. 2018.

Suwartono. Dasar-Dasar Metodologi Penelitian. Yogyakarta: CV. Andi Offset 2014.

Dewayani, Sofie. Roosie Setiawan. Saatnya Bercerita: Mengenalkan Literasi Sejak Dini. Yogyakarta: PT Kanisius. 2018.

Zuhairini. Filsafat Pendidikan Islam. Jakarta: Bumi aksara. 2012. 